\title{
Carcinoma of the Lacrimal Gland pT3 TNM Finding $v 7$
}

National Cancer Institute

\section{Source}

National Cancer Institute. Carcinoma of the Lacrimal Gland pT3 TNM Finding v7. NCI

Thesaurus. Code C88793.

Carcinoma of the lacrimal gland with tumor measuring more than $4 \mathrm{~cm}$ in greatest dimension. Note: As the maximum size of the lacrimal gland is $2 \mathrm{~cm}, \mathrm{~T} 2$ and greater tumors will usually extend into the orbital soft tissue. (from AJCC 7th Ed.) 